\title{
INTERJEKSI DALAM BAHASA INDONESIA: ANALISIS PRAGMATIK
}

\author{
Bambang Widiatmoko \\ Fakultas Keguruan dan Ilmu Pendidikan Universitas Islam "45" \\ email: bangwidi_66@yahoo.com \\ HP 081385987069
}

\author{
Waslam \\ Fakultas Ilmu Komunikasi Universitas Esa Unggul \\ email: sswaslam@gmail.com \\ HP : 081387812063
}

\begin{abstract}
ABSTRAK
Dalam buku Tata Bahasa Baku Bahasa Indonesia dijelaskan bahwa interjeksi atau kata seru adalah kata tugas yang mengungkapkan rasa hati pembicara. Berbeda dengan kelas kata lain (yaitu verba, ajektiva, adverbial, dan nomina), kata tugas hanya memiliki makna gramatikal dan tidak memiliki arti leksikal. Dalam penelitian ini penulis membahas interjeksi dalam bahasa Indonesia dengan menggunakan analisis pragmatik. Tujuan penelitian ini adalah menemukan dan menjelaskan faktor utama pembentuk interjeksi dalam bahasa Indonesia. Hasil penelitian menunjukkan bahwa faktor untama pembentuk interjeksi dalam bahasa Indonesia adalah faktor makna kata/makna satuan bahasa dan situasi bicara.
\end{abstract}

\section{Kata Kunci: interjeksi, kata tugas, arti gramatikal, arti leksikal, pragmatik, makna kata, situasi bicara.}

\begin{abstract}
In the Bahasa Indonesia standard book, i.e. Tata Bahasa Baku Bahasa Indonesia it is explained that interjections is a task word that expresses the speaker's heart. Unlike other word classes (i.e. verbs, ajectives, adverbials, and nouns), the interjection has only grammatical meaning and has no lexical meaning. In this study, the author discusses interjection in the Bahasa Indonesia by using pragmatic analysis. The objective of the study was to find and explain the main factors of the interjection forming in Bahasa Indonesia. The results showed that the main factor forming interjection in Bahasa Indonesia is the meaning of the word (or the unit of language) and speech situation.
\end{abstract}

Key Words: interjection, task word, grammatical meaning, lexical meaning, pragmatic analysis, word meaning speech situation.

\section{PENDAHULUAN}

Dalam Tata Bahasa Baku Bahasa Indonesia dijelaskan bahwa interjeksi atau kata seru adalah "kata tugas yang mengungkapkan rasa hati pembicara. Untuk memperkuat rasa hati 
seperti rasa kagum, sedih, heran, dan jijik, orang memakai kata tertentu di samping kalimat yang mengandung makna pokok yang dimaksud (2003: 303). Berbeda dengan kelas kata lain (yaitu verba, adjektiva, adverbial dan nomina), kata tugas hanya mempunyai arti gramatikal dan tidak memiliki arti leksikal.

Interjeksi termasuk kelas kata dalam banyak bahasa, termasuk bahasa Indonesia. Sejauh ini, analisis mengenai interjeksi dalam bahasa Indonesia relatif masih sedikit sehingga pemerian tentang interjeksi dalam buku-buku tata bahasa Indonesia kurang menunjukkan perkembangan yang siginifikan. Sehubungan dengan itu, perlu dilakukan analisis secara lebih intensif mengenai kelas kata ini. Fokus penelitian dapat ditujukan kepada sejumlah aspek, misalnya mengenai pemakaian interjeksi dalam konteks semantik-pragmatik dan pola pembentukan kalimat interjektif dalam bahasa Indonesia.

Sehubungan dengan latar belakang pemikiran tersebut, penulis melakukan penelitian tentang interjeksi dalam bahasa Indonesia. Pertanyaan penelitian adalah: bagaimanakah deskripsi pragmatik interjeksi dalam bahasa Indonesia? Tujuan penulisan adalah memberikan deskripsi pragmatik interjeksi dalam bahasa Indonesia.

\section{TINJAUAN PUSTAKA}

\section{Interjeksi}

Menurut Kamus Besar Besar Bahasa Indonesia (2015: 542) interjeksi adalah "kata seruan yang mengungkapkan suatu perasaan". Menurut Kridalaksana (2015: 93) "interjections are words used to express the emotion of the speaker, with its relevant intonation" ("interjeksi adalah kata-kata yang digunakan untuk mengungkapkan emosi penutur dengan menggunakan intonasi yang relevan'). Sementara itu, Oxford Advanced Learner's Dictionary of Current English karya A.S. Hornby mendefinisikan lema interjeksi sebagai "a short sound, word or phrase spoken suddenly to express an emotion" (2003: 710).

Menurut Chaer (2011: 193) kata seru adalah kata-kata yang digunakan untuk mengungkapkan perasaan batin, misalnya karena kaget, terharu, kagum, marah, atau sedih. Dilihat dari segi strukturnya, terdapat dua macam kata seru, yaitu:

a. Kata seru yang berupa kata-kata singkat, seperti wah, ci, hai, o, oh, nah, ha, dan hah.

b. Kata seru yang berupa kata-kata biasa, seperti aduh, celaka, gila, kasihan, bangsat, ya ampun. Serta kata-kata serapan astaga, masya Allah, alhamdulillah, dan sebagainya.

Kalimat seruan digunakan untuk menyatakan emosi atau perasaan batin yang biasanya terjadi secara tiba-tiba. Misalnya rasa terkejut, marah, kagum, gemas, kecewa, sedih, semas, takut, tidak suka, benci, dan iba.

Menurut Effendi (2015: 33) kata dalam bahasa Indonesia dapat dibagi dalam tiga golongan, yaitu (1) golongan kata bersistem terbuka, kata utama (kata leksikal), (2) golongan kata bersistem tertutup, kata tugas (kata gramatikal), dan (3) golongan kata bersistem khusus, kata bilangan. Golongan kata bersistem terbuka mencakup empat jenis kata, yaitu: (a) kata benda (nomina), (b) kata kerja (verba), (c) kata sifat (adjektiva), dan (d) kata keterangan (adverbia). Adapun golongan kata bersistem tertutup mencakup, antara lain, lima jenis kata, yaitu: (a) kata depan (preposisi), (b) kata penghubung (konjungsi), (c) kata ganti (pronomina), (d) kata sandang (artikel), dan (e) kata seru (interjeksi). Contoh interjeksi adalah oh, wah, amboi, aduh. Sementara itu, golongan kata yang bersistem khusus terdiri atas: (a) kata bilangan tentu dan (b) kata 
bilangan tak tentu. Menurut Kusno (1986: 90) kata seru atau interjectio adalah kata yang dipakai untuk menyatakan luapan emosi atau perasaan.

Menurut Kridalaksana, baik secara komunikatif maupun secara diskursif interjeksi merupakan bagian suatu tuturan. Namun, secara sintaksis, interjeksi bukanlah konstituen langsung kalimat yang terletak di belakangnya sehingga interjeksi dikategorikan sebagai extrasentencial. Interjeksi terbagi dua, yaitu interjeksi sederhana (simple interjections) dan interjeksi turunan (derived interjections). Hal ini diuraikan dalam di Tabel 1.

Tabel 1.

Pembagian Interjeksi menurut Bentuknya

(sumber: Kridalaksana, [2015: 93] )

\begin{tabular}{|l|l|l|}
\hline No. & \multicolumn{1}{|c|}{ Deskripsi } & \multicolumn{1}{|c|}{ Contoh } \\
\hline 1. & $\begin{array}{l}\text { Interjeksi sederhana (simple } \\
\text { interjections) }\end{array}$ & $\begin{array}{l}\text { aduh, aduhai, ah, ahoi, ai, amboi, } \\
\text { bah, cih, cis, eh, hai, he, idih, in, } \\
\text { lho, oh, sst, wah, wahai, yaa } \\
\text { (ungkapan kekecewaan) }\end{array}$ \\
\hline 2. & $\begin{array}{l}\text { Interjeksi turunan (derived } \\
\text { interjections) }\end{array}$ & $\begin{array}{l}\text { alhamdulillah, ampun, astaga, } \\
\text { asyik, asyoi, astagafirullah [sic], } \\
\text { brengsek, buset, duilah, masya } \\
\text { allah, syukur, oke, innalillahi, } \\
\text { yahud }\end{array}$ \\
\hline
\end{tabular}

Menurut Kusno (1986: 90) terdapat beberapa ciri penting kata seru atau interjeksi. Pertama, kata seru dapat berdiri sendiri sebagai kalimat tidak lengkap. Kedua, kata seru tidak menduduki jabatan tertentu di dalam kalimat dan terpisah dari bangun kalimat yang ditempatinya. Ketiga, kata seru dapat menyatakan luapan emosi atau perasaan yang berbedabeda, sesuai dengan hubungannya dalam kalimat. Keempat, kata seru merupakan kata yang paling tua dan bersifat umum. Artinya, kata seru adalah kata yang paling dulu digunakan oleh manusia dalam proses kebahasaannya dan hampir setiap bahasa mempunyai kata seru yang sama, misalnya oh, ah, hai, dan he.

Contoh pemakaian kata seru:

a. Aduh!

b. Aduh, dia lagi yang muncul.

c. Aduh, tingginya bangunan itu.

d. Aduh, bagaimana ini?

e. Aduh, ini anak!

Semua contoh di atas menunjukkan bahwa sebagai kata seru, aduh dapat mendukung makna yang berbeda-beda seperti halnya kata seru yang lain. Selanjutnya, menurut Kusno BS, dalam bahasa Indonesia dikenal tiga macam kata seru, yaitu:

a. Kata seru asli: ah, oh, ha, bah, cih, cis, wah, dan sebagainya. 
b. Kata seru yang berasal dari jenis kata lain, dan mempunyai makna leksikal: astaga, ampun, syukur, gila, keparat, kasihan, awas, dan sebagainya.

c. Kata seru yang berupa ungkapan: celaka dua belas, alhamdulillah, innalillahi, astaghfirullah, dan sebagainya.

Berkaitan dengan jenis-jenis kalimat Effendi et. al. (2015: 236-239) menggabungkan kalimat pernyataan, kalimat pertanyaan, kalimat perintah, dan kalimat seruan dalam satu kelompok pembahasan. Dikatakan bahwa kalimat seruan adalah "kalimat atau tuturan yang menunjukkan perasaan penuturnya, biasanya ditandai dengan alangkah, betapa, atau frasa bukan main atau kata seruan biasa." Contoh:

a. Alangkah bodohnya aku selama ini!

b. Betapa mulianya hatimu, Nak!

c. Bukan main uletnya anak itu!

d. Luar biasa!

e. Wah, kalah lagi!

Definisi mengenai kalimat seru dalam buku tatabahasa yang serumpun dengan bahasa Indonesia, misalnya bahasa Malaysia, cenderungan sama substansinya. Kalimat seru (atau ayat seruan dalam bahasa Malaysia) didefinisikan sebagai ayat yang diucapkan dengan membawa nada atau intonasi seruan untuk tujuan melahirkan suatu keadaan perasaan, seperti takut, marah, takjub, geram, dan sakit. Intonasi seruan ini digambarkan di dalam tulisan dengan tanda seru (!) yang biasanya terletak di akhir ayat atau kalimat. Kata seru yang sering digunakan adalah oh, amboi, wah, cis, eh, aduh, dan syabas. (Karim, 1986: 56-57). Contoh:
a. Ibu!
b. Anakku!
c. Comelnya!
d. Oh, Tuhanku!
e. Amboi, garangnya!
f. Wah, besarnya kereta abang!
g. Cis, terimalah tikamanku ini!
h. Eh, Ali rupanya sudah datang!
i. Nah, ambillah uang ini!
j. Aduh, bisanya!
k. Syabas, engkau telah menang!

Interjeksi dalam bahasa Indonesia dapat diklasifikasikan menurut aspek emosi penutur. Dalam hal ini, interjeksi dapat dibagi dalam delapan jenis, sebagaimana diuraikan pada Tabel 2.

Tabel 2.

Penggolongan Interjeksi menurut Segi Emotif Penutur (sumber: Kridalaksana, [2015: 94] )

\begin{tabular}{|c|l|l|}
\hline No. & \multicolumn{1}{|c|}{ Deskripsi } & \multicolumn{1}{|c|}{ Interjeksi } \\
\hline 1 & $\begin{array}{l}\text { Interjeksi yang menyatakan imbauan untuk } \\
\text { memperhatikan sesuatu }\end{array}$ & $\begin{array}{l}\text { ahoi, eh, hai, he, sst, } \\
\text { wahai. }\end{array}$ \\
\hline 2. & Interjeksi yang menunjukkan rasa terkejut atau & aduhai, amboi, astaga, \\
\hline
\end{tabular}




\begin{tabular}{|c|l|l|}
\hline & takjub & asyoi, wah, yahud \\
\hline 3. & $\begin{array}{l}\text { Interjeksi yang mengungkapkan rasa sakit atau } \\
\text { sedih }\end{array}$ & aduh. \\
\hline 4. & Interjeksi yang menyatakan simpati & innalillahi \\
\hline 5. & $\begin{array}{l}\text { Interjeksi yang menyatakan kekecewaan atau } \\
\text { kekesalan }\end{array}$ & ah, brengsek, buset, yaa \\
\hline 6. & $\begin{array}{l}\text { Interjeksi yang menyatakan perasaan kaget } \\
\text { dan terpukul }\end{array}$ & $\begin{array}{l}\text { ampun, lho, masyaallah, } \\
\text { astagafirullah [sic.] }\end{array}$ \\
\hline 7. & $\begin{array}{l}\text { Interjeksi yang menyatakan pujian dan terima } \\
\text { kasih }\end{array}$ & alhamdulillah, syukur \\
\hline 8. & $\begin{array}{l}\text { Interjeksi yang menyatakan rasa tidak suka } \\
\text { dan muak }\end{array}$ & ampun, bah, cis, idih \\
\hline
\end{tabular}

Kridalaksana menyatakan bahwa interjeksi berbeda dengan bentuk fatis (phatics). Fungsi bentuk fatis adalah mengawali, mempertahankan, membatasi, atau mempertegas aspek-aspek tertentu komunikasi di antara komunikan. Pada umumnya --namun tidak selalu - bentuk fatis ditemukan dalam dialog atau percakapan. Sebagian besar bentuk fatis digunakan dalam kelompok tertentu penutur dengan identitas yang sama dalam suasana tidak formal.

Menurut Kridalaksana, sejumlah tata bahasawan memasukkan bentuk fatis ke dalam interjeksi. Namun, apabila ditinjau secara sintaksis maupun secara semantik, pandangan ini tidak dapat dipertahankan. Secara sintaksis, interjeksi muncul hanya pada awal suatu tuturan, sedangkan bentuk fatis dapat muncul pada awal, tengah, maupun akhir tuturan. Di sisi lain, secara semantis, interjeksi hanya menunjukkan aspek emosi (perasaan) penutur, sedangkan bentuk fatis digunakan dengan fungsi komunikatif yang bervariasi, yang tidak selalu merupakan ungkapan emosi atau perasaan.

Terdapat dua jenis bentuk fatis dalam bahasa Indonesia, yaitu: (a) bentuk fatis bebas, seperti: kok, deh, selamat, assalamu'alaikum, ya; (b) bentuk fatis terikat, seperti: lah, pun. Pada Tabel 3 ditunjukkan posisi bentuk fatis dalam kalimat.

Tabel 3:

Posisi Bentuk Fatis dalam Kalimat

(sumber: Kridalaksana, [2015: 85] )

\begin{tabular}{|l|l|l|}
\hline No. & \multicolumn{1}{|c|}{ Posisi Bentuk Fatis } & \multicolumn{1}{c|}{ Contoh } \\
\hline 1. & Awal kalimat & Kok kamu pergi juga? \\
\hline 2. & Pertengahan kalimat & Bukan dia, kok, yang mengambil uang itu. \\
\hline 3. & Akhir kalimat & Saya hanya lihat-lihat saja, kok. \\
\hline
\end{tabular}

Setakat dengan ini, Kridalaksana mengakui bahwa bentuk fatis yang terletak pada awal kalimat -- khususnya apabila digunakan dengan nada bercorak emotif -- sulit dibedakan dengan interjeksi.

\section{Pragmatik}


Istilah pragmatik digunakan pertama kali oleh Charles Morris pada tahun 1938, untuk menggambarkan sifat filsafat yang dikembangkan oleh Charles S. Peirce, yaitu pragmatisme atau pragmatisisme. Secara etimologis, kata pragmatik, pragmatisme, dan pragmatisisme diturunkan dari akar kata bahasa Yunani pragma yang bermakna 'tindakan atau perbuatan.

Morris memasukkan pragmatik sebagai salah satu bagian semiotik. Menurut Morris, semiotik dibagi dalam tiga tipe, yaitu sintaksis (relasi formal antara satu tanda dengan tanda lain), semantik (yaitu hubungan tanda dengan segala sesuatu yang diacu oleh tanda itu), dan pragmatik (yaitu hubungan tanda dengan penggunanya). Pengguna tanda itu adalah manusia, baik yang memproduksi tanda maupun yang memahami/menangkap tanda. Dalam memproduksi atau menangkap tanda, pengguna selalu melakukan penafsiran-penafsiran berdasarkan konteks, latar, dan hubungan antarpengguna dengan tanda.

Levinson (dalam Subroto, 2008: 507) menyatakan "pragmatics is the study of those relations between language and context that are grammaticalized or encoded in the structure of language". Artinya, pragmatik adalah studi tentang hubungan antara bahasa dan konteks yang digramatikalkan atau dikodekan dalam struktur bahasa. Maksudnya, konteks turut menentukan maksud tuturan dan turut menentukan pilihan struktur bahasa (pilihan intonasi, pilihan kata, struktur morfologi, dan sruktur kalimat yang dipakai). Lebih lanjut Levinson menyatakan "pragmatics is the study of the relations between language and context that are basic to an account of language understanding (the context-dependent)". Pragmatik tidak dapat dipahami maksudnya tanpa adanya konteks; maksud tuturan secara pas hanya dapat dipahami dalam hubungan konteks.

Banyak ahli pragmatik berpendapat bahwa terdapat hubungan yang sangat erat antara semantik dan pragmatik sehingga sulit membuat pemisahan yang tegas antara keduanya (Subroto, 2008: 506). Baik pramatik maupun semantik sama-sama mengkaji arti, namun dari kaca mata yang berbeda. Semantik mengkaji arti bahasa (arti lingual), sedangkan pragmatik mengkaji arti menurut sang penutur. Menurut Siregar (2004: 163) semantik dan pragmatik di antaranya dibedakan dengan "apa yang dikatakan" dan "apa yang dimaksudkan".

Pragmatik dan semantik sama-sama menggunkan makna sebagai isi komunikasi. Semantik berpusat pada pikiran (competence, langue), sedangkan pragmatik berpusat pada ujaran (performance, parole). Levinson (dalam Sudaryat, 2009: 120) menyatakan "pragmatics is concerned solely with performance principles of language usage and the disambiguation of sentence by the contexts in which they were uttered. Pragmatics is the study of the relation between language and contexts that are basic to an account of language ... standing." Crystal (dalam Sudaryat 2009: 12) mengemukakan bahwa pragmatik merupakan kajian yang menghubungkan struktur bahasa dan pemakaian bahasa, seperti ditunjukkan oleh Bagan 1 .

Bagan 1: Fungsi Pragmatik

(sumber: Crystal [dalam Sudaryat, 2009: 12]) 


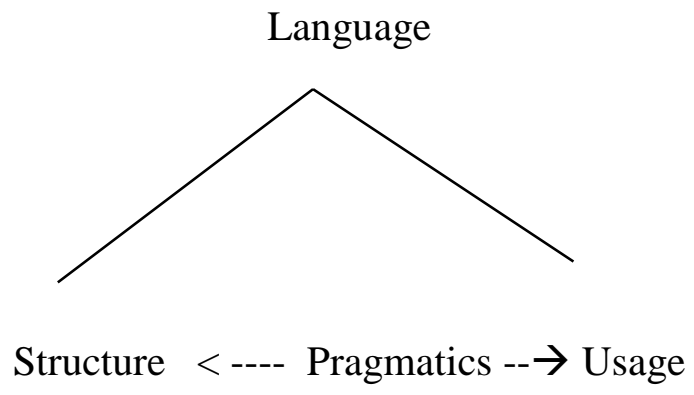

Arti bahasa yang menjadi bidang kajian semantik adalah arti kata-kata yang dipakai dalam sebuah kalimat serta arti kalimat sesuai dengan strukturnya. Arti lingual tidak bergantung pada konteks dan biasa disebut arti yang bersifat natural (natural meaning).Di sisi lain, arti yang menjadi bidang kajian pragmatik bersifat tidak natural (non-natural meaning). Arti yang menjadi bidang kajian pragmatik sangat bergantung pada konteks, yaitu: siapakah penuturnya, kepada siapa penutur berbicara, bagaimanakah hubungan antara penutur dan mitra tutur, apa yang menjadi motif bertutur, dalam rangka apa penutur itu bertutur, tujuannya apa, di manakah tuturan itu terjadi, dan sebagainya.

Sehubungan dengan itu, Gazdar (dalam Subroto, 2008: 507) menyatakan bahwa pragmatik adalah studi semua aspek arti yang tidak termasuk dalam teori semantik. Definisi ini dirumuskan sebagai berikut: Pragmatics = meaning - truth condition, maksudnya adalah: pragmatik mengkaji arti yang terdapat pada tuturan atau ujaran (utterance) minus kondisikondisi kebenaran (truth condition). Yang dimaksud dengan kondisi kebenaran adalah semantik kondisi kebenaran (truth condition semantics), yaitu prinsip penggunaan bahasa yang mengungkapkan fakta-fakta, memerikan benda atau hal-hal yang ada, menyajikan informasi yang dapat benar dan dapat salah. Semantik kondisi kebenaran lebih berorientasi kepada arti kata yang dipakai beserta arti kalimat menurut strukturnya dalam rangka mengungkapkan sesuatu.

Konteks memegang peranan penting dalam studi pragmatik. Konteks menyangkut segala sesuatu yang terdapat di sekitarnya atau lingkungannya yang memungkinkan adanya interaksi antarpeserta tutur dalam proses komunikasi, yang memungkinkan ekspresi kebahasaan dalamintgeraksi itu dapat dipahami. Konteks dalam pramatik juga berkaitan dengan praanggapan (presposisi), implikatur (kaitannya dengan eksplikatur), serta semua pengetahuan latar para peserta tutur. Menurut Subroto (2008: 511) pengertian konteks dalam studi pragmatik (khususnya sosiopragmatik) dapat dinyatakan sebagai berikut.

a. Konteks adalah sesuatu yang bersifat dinamis, bukan sesuatu yang statis.

b. Konteks menyangkut benda-benda dan hal-hal yang terdapat di tempat dan waktu pada saat tuturan terjadi.

c. Konteks berkaitan dengan interaksi antara penutur dan mitra tutur menyangkut variabel kekuasaan, status sosial, jarak sosial, umur, dan jenis kelamin.

d. Konteks juga berkaitan dengan kondisi psikologis penutur dan mitra tutur selama proses interaksi dan motif tuturan.

e. Konteks juga menyangkut presuposisi, pengetahuan latar, skemata, dan implikatur

f. Termasuk dalam konteks yang bersifat fisik adalah warna suara dan nada suara para peserta tutur. 
Beberapa contoh kalimat interjektif yang terdapat dalami buku-buku sumber menunjukkan pentingnya aspek konteks dalam memahami makna suatu tuturan seruan atau interjektif. Misalnya

a. Aduh!

b. Aduh, bagaimana ini?

c. Aduh, ini anak!

d. Luar biasa!

e. Wah, kalah lagi!

Makna tuturan (a) sampai dengan (e) baru dapat dipahami jika pendengar memahami waktu dan tempat saat tuturan itu diucapkan serta mengetahui situasi di sekitarnya. Tanpa dipenuhinya persyaratan in, semui tuturan tersebut tidak bermakna. Dengan demikian, tuturan (a) sampai dengan (e) bersifat universal yang ditentukan oleh berbagai konteks.

Sudaryat (2009: 146) menyatakan bahwa konteks wacana yang mendukung pemaknaan ujaran, tuturan, atau wacana adalah situasi kewacanaan. Situasi kewacanaan berkaitan erat dengan tindak tutur. Dalam bahasa Indonesia komponen tutur yang merupakan konteks kewacanaan dapat disingkat dengan WICARA yang fonem awalnya mengacu kepada: W(aktu, tempat dan suasana); I (nstrumen yang digunakan); C (ara dan etika tutur); (A)lur ujaran dan pelibat tutur); R (asa, nada, dan ragam bahasa); dan A (manat dan tujuan tutur).

Faktor penting lain dalam proses komunikasi adalah pelibat tutur. Pelibat tutur menyangkut penyapa (pembicara/penulis) dan pesapa (penyimak/pembaca). Berlangsungnya komuinikasi bahasa antara penyapa dan pesapa berpusat pada objek yang dibicarakan. Hubungan antara penyapa, pesapa dan objek yang dibicarakan ditunjukkan oleh Bagan 2.

Bagan 2: Pelibat Tutur

(sumber: Sudaryat [2009: 148])

Objek yang

Dicerminkan

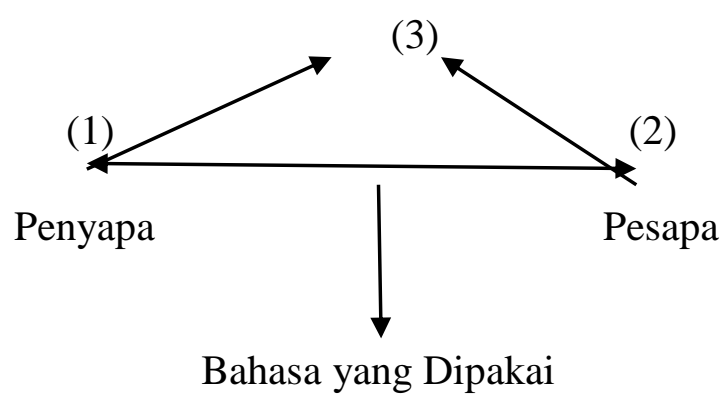

Aspek penting yang berhubungan erat dengan pragmatik adalah kognisi. Sejak lama para linguis mencoba menelaah sejauh manakah hubungan antara bahasa dan kognisi mengingat keduanya berkaitan erat. Dalam konteks ini lahirlah linguistik kognitif, yang memandang pengetahuan akan linguistik sebagai bagian tidak terpisahkan dari sistem kognisi dan pemikiran manusia secara umum. Perilaku linguistik tidak terpisahkan dari kemampuan kognitif umum 
lainnya yang memungkinkan berlangsungnya proses penalaran, pengingatan, ataupun pembelajaran. Linguistik kognitif muncul pada akhir tahun 1970-an dan awal 1980-an, khususnya dengan terbitnya karya-karya George Lakoff (salah satu tokoh pendiri Semantik Generatif) dan Ronald Langacker. Sebagai konsekuensinya, paradigm baru ini dapat dipandang sebagai reaksi terhadap paradigma- generatif.

Konsep "adanya hubunga antara bahasa dan kognisi" dapat pula diterapkan dalam analisis kalimat, termasuk kalimat interjektif. Pada dasarnya.seruan seseorang yang terekspresikan melalui kalimat interjektif ada hubungannya dengan apa yang ada di dalam pikiran. Proses pembentukan kalimat seruan sebagaimana dijelaskan oleh Chaer (2011: 360) dapat digambarkan sebagai berikut: Kalimat interjektif = kata seru + klausa yang menyatakan isi perasaan.Mernurut skema ini, klausa yang menyatakan isi perasaan bersifat bebas. Jenis kalimat interjektif ini ditentukan oleh isi perasaannya.

Ditilik dari isi perasaan penutur dalam kalimat interjektif berdasarkan kata seru yang digunakan, setidaknya terdapat dua kelompok utama tindak tutur, yaitu:: (a) Tindak tutur yang santun, yang tercermin melalui penggunaan kata-kata seru seperti: alhamdulillah, masyaallah, innalillah, subhanallah, laa haula wa laa quwwata illa billah (b) Tindak tutur tidak santun, yang tercermin melalui penggunaan kata-kata seru seperti: bangsat, bajingan, kurang ajar.

METODE PENELITIAN

Untuk menguraikan paparan dalam penelitian ini, pnulis memakai metode deskriptif. Suryabrata (2005: 75-76) mengatakan bahwa tujuan penelitian deskriptif adalah untuk membuat pencandraan secara seistematis, faktual, dan akuratmenganai fakta-fakta dan sifat-sifat populasi atau daerah tertentu.

Secara harfiah, penelitian deskriptif adalah penelitian yang bermaksud untuk membuat pencandraan (deskripsi) mengenai situasi-situasi atau kejadian-kejadian. Dalam arti ini penelitian deskriptif ini adalah akumulasi data dasar dalam caara desktiptif semata-mata tidak mencari atau menerangkan saling hubungan, menguji hipotesis, membuat ramalan, atau mendapatkan makna dan implikasi, walaupun penelitian bertujuan untuk menemukan hal-hal tersebut dapat mencakup juga metode-metode deskriptif.

Penelitian ini bersifat deskriptif. Data yang berkaitan dengan interjeksi diambil dari sumber-sumber sebagai berikut.

a. Buku Tata Bahasa Baku Bahasa Indonesia terbitan Departemen Pendidikan Nasionaledisi tahun 2003.

b. Buku Tata Bahasa Acuan Bahasa Indonesia karya S. Effendi, edisi tahun 2015

c. Buku Tata Bahasa Dasar Bahasa Indonesia karya S. Effendi et.al, edisi tahun 2015

d. Buku Tata Bahasa Praktis Bahasa Indonesiakarya Abdul Chaer, edisi revisi tahun 2011.

e. Buku Introduction to Word Formation and Word Classes in Indonesian karya Harimurti Kridalaksana, edisi tahun 2014.

Buku Tata Bahasa Baku Bahasa Indonesia terbitan Departemen Pendidikan Nasional adalah sumber standar. Data yang termuat di dalamnya dianggap mewakili keseluruhan data, dalam hal ini adalah kata seru (intejeksi) dalam bahasa Indonesia. Buku Tata Bahasa Acuan Bahasa Indonesia karya S. Effendi dan Tata Bahasa Dasar Bahasa Indonesia karya S. Effendi et.al terbit berselang setahun dengan pelaksanaan penelitian ini. Edisi pertama kedua buku tersebut terbit pada tahun 2015. Dengan demikian, kedua buku ini memuat pandangan mutakhir linguis atau pakar bahasa Indonesia mengenai interjeksi bahasa Indonesia. Sementara itu, buku 
Tata Bahasa Praktis Bahasa Indonesia karya Abdul Chaer dan Introduction to Word Formation and Word Classes in Indonesian karya Harimurti Kridalaksana dipilih sebagai pelengkap. Interjeksi yang terdapat dalam buku sumber dicatat dan dikelompokkan berdasarkan jenisnya, selanjutnya dianalisis menggunakan pendekatan pragmatik.

\section{HASIL DAN PEMBAHASAN}

\section{a. Pengantar}

Berdasarkan tinjauan literatur di depan, tampak bahwa pandangan kalangan tatabahasawan mengenai definisi interjeksi serta kedudukan dan dan fungsinya dalam gramatika relatif cukup beragam. Secara historis, interjeksi dalam berbagai bahasa alami (natural languages) diperlakukan dengan dua cara: pertama, sebagai bagian dari bahasa, dan kedua, sebagai bentuk nonlinguistik yang menunjukkan perasaan hati atau pikiran..

Libert (2011) secara khusus melakukan studi tentang interjeksi. Ia berpendapat bahwa definisi tentang interjeksi yang terdapat dalam berbagai sumber cenderung kabur dan ambigu. Dalam berbagai definisi mengenai interjeksi tersebut, pengertian interjeksi sering kali bertumpang tindih dengan kelas kata lain.

Menurut Libert, interjeksi memiliki karakter yang heterogen. Hal ini tercermin dari sejumlah penjelasan atau definisi pakar. Misalnya, Cuenca (dalam Libert, 2011: 284) menyatakan "interjections are a heterogeneous class including onomatopoeic words, one word elements (ouch, oh, wow, oops...), and phrasal elements (thank you, good heavens, for God's sake)". Senada dengan itu, Wharton menyatakan:

According to various definitions in the literature, interjections are a fairly heterogeneous class of items. Examples in English include wow, yuk, aha, ouch, oops, ah, oh, er, huh,eh, tut-tut (tsk-tsk), brrr, shh, ahem, psst, and even, according to some, bother, damn, (bloody) hell, shit (etc.), goodbye, yes, no, thanks, well. (...)

[Menurut berbagai definisi di dalam literatur, interjesi termasuk kelas kata yang heterogen. Misalnya, interjeksi dalam bahasa Inggris mencakup bentuk-bentuk seperti wow, yuk, aha, ouch, oops, ah, oh, er, huh,eh, tut-tut (tsk-tsk), brrr, shh, ahem, dan psst. Bahkan, menurut sebagian penulis, bentuk bother, damn, (bloody) hell, shit, goodbye, yes, no, thanks, well juga termasuk interjeksi (...) ]

Menurut pendapat Libert, penjelasan Wharton mengenai keheterogenan interjeksi tersebut tidak seluruhnya benar. Libert, misalnya, tidak setuju jika bentuk-bentuk onomatopoeia digolongkan sebagai interjeksi. Selain itu, Libert juga tidak sependapat jika thank you atau sorry digolongkan sebagai interjeksi karena bentuk ini sangat berbeda dengan oh, misalnya. Libert lebih cenderung menggolongkan interjeksi dalam kelas kata tersendiri dengan cakupan yang sempit. Menurut Libert, interjeksi memiliki hanya satu fungsi, yaitu sebagai 'ekspresi perasaan' sedangkan fungsi yang lain terdapat pada kelas kata yang lain. Menurut Libert, interjeksi adalah kelas kata yang homogen

Sejauh ini, studi mengenai segi semantik dan pragmatik interjeksi terfokus pada tiga masalah pokok. Pertama, apa sajakah yang dikomunikasikan oleh interjeksi? Kedua, apa sajakah fungsi interjeksi, dan ketiga, apakah interjeksi bagian dari bahasa? Ketiga permasalahan ini 
didekati oleh para ahli bahasa dengan sudut-pandang dikotomis. Ameka (1992), Wierzbicka (1992), dan Wikins (1992) memperlakukan interjeksi sebagai bagian dari bahasa. Sedangkan penulis lain, seperti Goffman (1981) menyatakan bahwa interjeksi tidak termasuk dalam kajian bidang linguistik. Menurut pandangan terakhir, interjeksi bukan merupakan bagian bahasa sehingga lebih tepat dianalisis dalam konteks peran sosio-komunikatif dan bukan sebagai kajian linguistik.

Selaras dengan itu, pandangan para tata bahasawan Indonesia mengenai interjeksi dalam bahasa Indonesia merefleksikan dua sudut pandang ini. Kridalaksana, misalnya, berpendapat bahwa interjeksi bukan bagian dari bahasa. Dasar pertimbangannya, baik secara komunikatif maupun secara diskursif, interjeksi merupakan bagian suatu tuturan. Namun, secara sintaksis, interjeksi bukan konstituen langsung kalimat sehingga lebih tepat dikategorikan sebagai extrasentencial.

Biasanya, pendapat bahwa interjeksi bukan bagian bahasa diperkuat dengan analisis struktur kalimat. Para tokoh pendukungnya menyatakan bahwa sejumlah kata, frase, bahkan klausa pendek yang berisi luapan emosi atau perasaan hati sang penutur dapat berfungsi sebagai interjeksi. Contoh: kalimat bahasa Inggris Emily has switched her major to chemistry adalah pernyataan biasa yang tidak mengekspresikan segi emosi apa pun. Dalam kalimat ini dapat digunakan ajektiva sebagai interjeksi, misalnya menjadi: Sweet! Emily has switched her major to chemistry. Atau dapat juga menggunakan nomina, contoh: Congratulations, Emily has switched her major to chemistry

\section{b. Penelitian Lain yang Relevan}

Kajian tentang intejeksi yang dilakukan oleh para peneliti biasanya ditekankan pada aspek-tertentu bahasa untuk melengkapi pemerian tentang ciri-ciri, struktur, dan fungsi interjeksi dalam suatu bahasa alami (natural language). Thi Khim Phuong, misalnya (2011) mengadakan penelitian tentang perbandingan antara interjeksi bahasa Inggris dan bahasa Vietnam. Ia menyimpulkan bahwa terdapat sejumlah persamaan namun juga perbedaan antara interjeksi bahasa Inggris dan Vietnam. Dalam konteks pragmatik, interjeksi dalam bahasa Vietnam dipengaruhi oleh nilai-nilai sosial budaya lokal sehingga memiliki karakteristik yang berbeda dengan interjeksi dalam bahasa Inggris.

Apabila dikaitkan dengan penelitian yang dilakukan oleh Kim Phuong, nampak bahwa terdapat kesamaan fungsi interjeksi bahasa Indonesia dengan interjeksi bahasa Inggris dan bahasa Vietnam. Dalam ketiga bahasa, yaitu bahasa Inggris, Vietnam,dan Indonesia interjeksi tunggal dapat mengisi berbagai jenis fungsi pragmatik, seperti rasa kaget, pernyataan amarah, pernyataan penolakan, komplimen, hesitasi, keraguan, kegembiraan, dan rasa puas. Dapat dipenuhinya berbagai jenis fungsi pragmatik oleh interjeksi tunggal ini dimungkinkan bukan hanya karena adanya kesesuaian konteks tempat suatu komunikasi berlangsung, melainkan juga karena adanya peran kognisi pemakai interjeksi dalam komunikasi.

Interjeksi dalam bahasa Inggris, Vietnam, dan bahasa Indonesia digunakan untuk menandai perasaan ekspresif dan perasaan emotif sang penutur dengan maksud lebih mengefektifkan komunikasi. Secara morfologis, proses pembentukan interjeksi cukup bervariasi. Sebagian besar interjeksi adalah kata asli bahasa Inggris atau Vietnam, sementara sebagian kecil adalah pinjaman dari bahasa lain. Bahasa yang kosakatanya paling banyak dipinjam oleh bahasa Inggris adalah bahasa Perancis, Afrika Selatan, atau Spanyol, sedangkan bahasa Vietnam banyak meminjam kosakata bahasa Cina (Kim Phuong, 2011: 20). Sementara itu, interjeksi bahasa Indonesia memiliki ciri khas tersendiri yaitu dengan cukup dominannya 
interjeksi yang berasal dari bahasa Arab, seperti alhamdulillah, insya allah, masya allah, dan innalillah.

Hardiah (2012) mengadakan penelitian mengenai interjeksi bahasa Indonesia dengan tujuan memberikan gambaran secara lebih menyeluruh mengenai bentuk, realisasi penggunaan, klasifikasi, dan fungsi interjeksi dalam komunikasi. Hasil analisisnya menunjukkan bahwa interjeksi dalam bahasa Indonesia dapat dikelompokkan atas dua kelompok besar yaitu bentuk primer (primary interjection) dan bentuk sekunder (secondary interjection). Bentuk primer (primary interjection) adalah interjeksi berupa kata-kata pendek dari tiruan bunyi, teriakan, ajakan, dan panggilan minta perhatian; sedangkan bentuk sekunder (secondary interjection) adalah interjeksi yang dapat menempati fungsi leksikal yang lain. Interjeksi bersifat ekstra kalimat yang mendahului ujaran yang menyertainya.selain itu interjeksi dapat berdiri sendiri sebagai sebuah ujaran yang memiliki makna dan sangat tergantung pada konteks. Klasifikasi interjeksi didasarkan atas 3 hal yaitu; (a) volitif, yang ditujukan langsung pada lawan tutur; (b) emotif, yang merupakan ekspresi perasaaan; dan (c) kognitif, sebagai hasil pemikiran penutur.

Interjeksi bersifat multifungsi artinya sebuah interjeksi dapat berfungsi mengekspresikan beragam perasaan yang berbeda sesuai dengan maksud penutur dan konteks yang menyertainya. Selain itu interjeksi dapat pula berfungsi untuk tujuan fatis seperti membuka percakapan dan mengganti topik pembicaraan. Hal ini selaras dengan penjelasan Kusno (1986: 90) bahwa bentuk aduh memiliki berbagai fungsi emotif sebagaimana tampak dalam contoh tuturan berikut:
a. Aduh!
b. Aduh, dia lagi yang muncul.
c. Aduh, tingginya bangunan itu.
d. Aduh, bagaimana ini?
e. Aduh, ini anak.

Thawabteh (2010) melakukan penelitian mengenai taraf kemungkinan penerjemahan interjeksi suatu bahasa ke dalam bahasa lain, dalam hal ini adalah penerjemahan interjeksi bahasa Arab ke dalam bahasa Inggris. Hasil penelitiannya menunjukkan bahwa teks terjemahan menggunakan salah satu dari tiga strategi-penerjemahan utama sebagai berikut: (1) menghindari interjeksi dalam bahasa sumber; (2) mempertahankan interjeksi dalam bahasa sumber; dan (3) menambahkan interjeksi ke dalam bahasa sasaran. Kesimpulannya, interjeksi sangat krusial dalam kegiatan penerjemahan, yaitu sebagai faktor pemerlengkap komunikasi. Tanpa kehadiran interjeksi dalam suatu teks terjemahan, sesungguhnya telah terjadi kegagalan dalam proses komunikasi maupun dalam hal penjalinan hubungan interpersonal (Thawabteh, 2010: 511).

Penelitian Thawabteh perlu ditindaklanjuti dalam konteks interjeksi dalam bahasa alami (natural languages) lainnya, termasuk bahasa Indonesia. Dalam konteks bahasa Indonesia, penelitian tentang penerjemahan interjeksi suatu bahasa sumber ke dalam bahasa bahasa sasaran (yaitu bahasa Indonesia) akan mengurangi "keterpinggiran" studi interjeksi dalam bahasa Indonesia. Di sisi lain, melalui penelitian ini pemerian tentang ciri-ciri linguistik maupun nonlinguistik interjeksi dalam bahasa Indonesia akan semakin lengkap.

Abdullah dan Talib (2009) mengadakan penelitian mengenai makna interjeksi dalam bahasa Inggris dan bahasa Arab. Dalam upaya menemukan apakah terdapat kesamaan di antara kedua bahasa tersebut, peneliti melakukan perbandingan antara interjeksi bahasa Arab dan bahasa Inggris . Penelitian ini dilakukan untuk melihat kemungkinan dilakukannya penggolongan interjeksi secara semantik sebagaimana yang pernah dirumuskan oleh 
Wierzbicka. Sebagaimana diketahui, berdasarkan aspek semantisnya, Wierzbicka membagi interjeksi dalam tiga kelompok, yaitu: (a) interjeksi emotif, (b) interjeksi volitif, dan (c) interjekti kognitif. Temuan Abdullah dan Talib menunjukkan bahwa hubungan satu-per-satu (one-to-one correspondence) antara interjeksi bahasa Inggris dan bahasa Arab tidak selalu dapat ditemukan. Konsekuensinya, dalam hubungan ini penggolongan interjeksi sebagaimana gagasan Wierzbicka tidak dapat diterapkan.

Dalam skripsinya, Prasetyowati (2009) menganalisis terjemahan interjeksi bahasa Inggris ke dalam bahasa Indonesia dalam cerita The Adventures of Sherlock Holmes karya Sir Arthur Conan Doyle. Terkait dengan strategi penerjemahan, peneliti menemukan setidaknya sembilan strategi penerjemahan interjeksi bahasa Inggris ke dalam bahasa Indonesia, di antaranya adalah: (a) penerjemahan secara literal, (b) penerjemahan dengan menggunakan interjeksi yang berbeda bentuknya namun sama maknanya, (c) penerjemahan dengan cara menambahkan unsur interjeksi, (d) penerjemahan dengan cara mengurangi unsur interjeksi, dan (e) penerjemahan dengan menggunakan kata pinjaman. Sebagai kesimpulan ia menyatakan bahwa demi perbaikan mutu terjemahan, penerjemah buku harus lebih memperhatikan konteks situasi pada saat suatu tuturan diucapkan. Dengan demikian, interjeksi dalam bahasa sumber (bahasa Inggis) dapat diterjemahkan ke dalam bahasa Indonesia dengan lebih baik lagi.

\section{SIMPULAN}

Pandangan kalangan tatabahasawan mengenai definisi interjeksi serta kedudukan dan dan fungsinya dalam gramatika relatif cukup beragam. Di sisi lain, definisi beragam tentang interjeksi itu cenderung kabur dan ambigu oleh karena sering kali memasukkan unsur-unsur noninterjeksi ke dalam definisi interjeksi.

Interjeksi dalam bahasa Indonesia dapat diklasifikasikan menurut aspek emosi penutur. Kridalaksana, misalnya, membaginya dalam delapan jenis, yaitu: a. Interjeksi yang menyatakan imbauan untuk memperhatikan sesuatu, b. Interjeksi yang menunjukkan rasa terkejut atau takjub, c. Interjeksi yang mengungkapkan rasa sakit atau sedih, d. Interjeksi yang menyatakan simpati, e. Interjeksi yang menyatakan kekecewaan atau kekesalan, f. Interjeksi yang menyatakan perasaan kaget dan terpukul, g. Interjeksi yang menyatakan pujian dan terima kasih, dan h. Interjeksi yang menyatakan rasa tidak suka.

Sejauh ini, penelitian mengenai interjeksi bahasa Indonesia relatif masih terbatas. Oleh karena itu, penulis merekomendasikan kepada rekan sejawat dan para peneliti untuk melakukan penelitian lebih lanjut mengenai berbagai aspek interjeksi bahasa Indonesia. Dengan demikian akan diperoleh deskripsi atau pemerian yang lebih komprehensif dan lebih akurat. Hal ini sangat bermanfaat, khususnya dalam konteks pengajaran interjeksi bahasa Indonesia di lembagalembaga pendidikan. 


\section{DAFTAR PUSTAKA}

Abdullah, Alia Badr dan Zahraa Nasir Talib. 2009. "The Meaning of Interjections in English and Arabic." Dalam Journal of the College of Arts University of Basra. No. 50. Diakses 30 November 2016.

Alwi, Hasan, et. al. 2003..Tata Bahasa Baku Bahasa Indonesia. Edisi ke-3 Jakarta: Balai Pustaka.

B.S., Kusno. 1986. Pengantar Tata Bahasa Indonesia. Bandung: CV Rosda.

Chaer, Abdul. 2009.Sintaksis Bahasa Indonesia (Pendekatan Proses). Jakarta: Rineka Cipta.

Chaer, Abdul. 2011. Tata Bahasa Praktis Bahasa Indonesia. Jakarta: Rineka Cipta.

Departemen Pendidikan Nasional. 2015. Kamus Besar Bahasa Indonesia. Edisi Keempat. Jakarta: GramediaPustaka Utama.

Departemen Pendidikan Nasional. 2003. Tata Bahasa Baku Bahasa Indonesia. Jakarta: Depdiknas.

Effendi, S. 2015. Tata Bahasa Acuan Bahasa Indonesia. Tangerang: Pustaka Mandiri.

Effendi, S. et. al. 2015. Tata Bahasa Dasar Bahasa Indonesia. Bandung: Remaja Rosdakarya.

Goddard, Cliff. 2010. "The Natural Semantics Metalanguage Approach”. Dalam Bernd Heine dan Heiko Narrog eds.) The Oxford Handbook of Linguistic Analysis. Oxford: Oxford University Press. 459--484. Akses 1 Desember 2016.

Hornby, A.S. Sixth edition. 2003. Oxford Advanced Learner's Dictionary of Current English. Oxford: Oxford University Press.

Kridalaksana, Harimurti. 2015. Introduction to Word Formation and Word Classes in Indonesian. Jakarta: Yayasan Pustaka Obor.

Libert, Alan Reed. 2011. "On conversational valence and definition of interjections". Dalam Proceedings of the $42^{\text {nd }}$ Australian Linguistic Society Conference 2011. ANU Research Repository-http://hdl.handle.net/1885/9418. Diakses 1 Desember 2016. 
Marusch, Tina. 2008. Natural Semantic Formalisms? A Discussion of the Naturalness in Wierzbicka's Approach to Lexical Semantic Analysis. Magisterarbeit. Philosophische Fakultat Professur Englische Sprachwissenschaft. Diakses 1 Desember 2016.

Nguyen Thi Kim Phuong. 2011. A Study of Linguistic Features of Interjections in English and Vietnamese. Danang: Ministry of Education and Training University of Danang.

Prasetyowati, Ratna. 2009. “An Analysis of Interjection Translation in Sir Arthur Conan Doyle's The Adventure of Sherlock Holmes." Skripsi. Surakarta: FSSR UNS.

Siregar, Bahren Umar. 2005. "Semantik-Pragmatik Metonimi dan Metafora". Dalam Sukamto, Katharina Endriati. (Penyunting). 2005. Menabur Benih Menuai Kasih Persembahan Karya Bahasa, Sosial, dan Budaya untuk Anton M. Moeliono pada Ulang Tahunnya yang ke-75. (Hlm. 163--178). Jakarta: Yayasan Obor Indonesa.

Subroto, H.D. Edi. 2008. "Pragmatik dan Beberapa Segi Metode Penelitiannya". Dalam Sukamto, Katharina Endriati. (Penyunting). Edisi ke-1. 2008. Kelana Bahana sang Bahasawan Persembahan untuk Prof. Soenjono Dardjowidjojo, Ph.D. dalam Rangka Ulang Tahunnya yang ke-70. Jakarta: Universitas Atma Jaya.

Sudaryat, Yayat. 2009. Makna dalam Wacana. Bandung: Yrama Widya.

Suryabrata, Sumadi. 2005. Metodologi Penelitian. Jakarta: PT Raja Grafindo Persada.

Sutami, Hermina. 2005. "Makna Senyuman: Analisis Tekstual terhadap Ungkapan Suasana Hati dan Tindakan Pikiran". Dalam Sukamto, Katharina Endriati (peny). 2005. Menabur Benih Menuai Kasih Persembahan Karya Bahasa, Sosial, dan Budaya untuk Anton M. Moeliono pada Ulang Tahunnya yang ke-75. (Hlm 373-391). Jakarta: Yayasan Obor Indonesa.

Thawabteh, Mohammad Ahmad. 2010. "The Translatability of Interjections: A Case Study of Arabic-English Subtitling”. Dalam Meta LV,3.( Diakses 30 November 2016)

Wharton, Tim. tt. Interjections, language and the 'Showing'/'Saying' Continuum. (Diakses 30 November 2016) 